\section{Importance of Collard and Kale Genotype for Winter Production in Southeastern United States}

\author{
M.W. Farnham ${ }^{1}$ \\ U.S. Department of Agriculture, Agricultural Research Service, U.S. Vegetable \\ Laboratory, 2875 Savannah Highway, Charleston, SC 29414-5334
}

J.T. Garrett ${ }^{2}$

Clemson University, PeeDee Research and Education Center, Florence, SC 29501

Additional index words. cole crops, Brassica oleracea L., Acephala Group, leafy greens, vernalization, bolting

\begin{abstract}
Winter production of collard and kale (Brassica oleracea L. Acephala Group) in the southeastern United States is limited by the tendency of these leafy green vegetables to bolt following vernalization. Collard and kale cultivars, landraces, and breeding lines were tested in four winter environments from 1992 to 1995 to determine differences among all included entries for winter production and tendency to bolt in a cold season environment. Essentially all entries survived the conditions of four winter environments. However, whether an entry reached harvest size depended on its date of $50 \%$ bolting. Collard typically bolted earlier than kale. Most kale entries reached a marketable size before bolting, while only the collard cultivars 'Blue Max' and 'Champion' and landraces G. Summersett and Mesic Zero consistently did the same. Several entries, for example, 'Squire' kale and G. Summersett collard, usually did not bolt. Results of this research indicate that significant genetic control of the long-standing (delayed bolting) phenotype is present in collard and kale. Successful winter production of these cole crops can be better ensured by using a long-standing genotype.
\end{abstract}

Collard and kale are important leafy green vegetables grown in the southeastern United States. Growers in this region wish to produce collard and kale year round, exploiting summer and winter, as well as the more reliable fall and spring environments. The greatest limitation to winter production of these greens is bolting before reaching marketable size. Low temperature-induced vernalization causes premature bolting (Parham and Moore, 1959) and makes the collard and kale crops unmarketable. Due to the propensity of collard and kale to bolt during winter, late fall plantings of these crops are not usually recommended in southeastern states (Dufault et al., 1992).

Cultivated forms of B. oleracea undergo a juvenile stage when low temperatures do not induce flowering (Warne, 1961). Following the juvenile stage, plants can then be stimulated to flower by a chilling treatment. Parham and Moore (1959) found that treatment of 2-

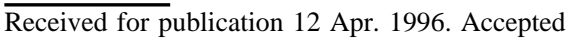
for publicaiton 13 July 1996. Mention of a trademark, proprietary product or vendor does not constitute a guarantee or warranty of the product by the U.S. Department of Agriculture and does not imply its approval to the exclusion of other products or vendors that might also be suitable. The cost of publishing this paper was defrayed in part by the payment of page charges. Under postal regulations, this paper therefore must be hereby marked advertisement solely to indicate this fact.

${ }^{1}$ Research Geneticist.

${ }^{2}$ Visiting Associate Professor.
3) determine if any genotypes attain marketable size under winter conditions before bolting.

\section{Materials and Methods}

Collard entries included the $\mathrm{F}_{1}$ hybrid cultivars 'Blue Max', 'Flash', 'Top Bunch', and 'Heavicrop', and the OP cultivars 'Vates', 'Champion', 'Georgia', 'Green Glaze', and 'Morris Heading'. In addition to the cultivars, four OP collard landraces were evaluated and designated as G. Summersett, J.Hope, Mesic Zero, and G. Simpson. Kale entries included the $\mathrm{F}_{1}$ hybrid cultivars 'Blue Armor' and 'Blue Knight', and five OP cultivars, 'Improved Dwarf Siberian', 'Premier', 'Vates', 'Squire' (also designated 'Squire 88'), and 'DwarfBlue Scotch'. Seed for all cultivars was obtained from commercial sources. OP landraces were obtained by M.W.F. from southeastern growers or gardeners that maintained seedstocks of these populations. In addition to 'Squire 88', two other 'Squire' populations, 'Squire 90' and 'Squire 92', were obtained from E.A. Borchers, Hampton Road Agricultural Experiment Station, Virginia Beach, Va. The three 'Squire' populations represent $\mathrm{C}_{0}, \mathrm{C}_{1}$, and $\mathrm{C}_{2}$ populations resulting from two cycles of recurrent selection for delayed bolting (also termed long-standing phenotype). An OP breeding population of kale, Red Green Glaze, obtained from E.A. Borchers, was also included.

Collard and kale entries were seeded in 150-cell seedling trays during Oct. 1992, 1993, and 1994 and grown in a heated greenhouse for $\approx 4$ to 6 weeks. One week before planting, transplants were set outdoors to condition them to cool weather before transplanting. All seedlings were at a three- to four-leaf stage when transplanted. In 1992, seedlings were transplanted to the field at Florence, S.C., on 6 Nov., and at Charleston, S.C., on 26 Nov. In 1993, seedlings were transplanted on 6 Dec. at Charleston, and in 1994, on 1 Dec. Soil type at Florence was a Norfolk loamy sand (structureless, fine-loamy, siliceous, thermic, typic Kandiudult) and at Charleston a Yonges loamy sand (fine loamy mixed, thermic Albaqualfs). The design of all field studies was a randomized complete block with four replications. Entries were randomized within replications and each experimental plot was a single row of $\approx 40$ plants of a given entry. Due to unavailability of seed of particular entries in certain years, G. Simpson collard and 'Dwarf Blue Scotch' kale were grown at both locations only in 1992-93, and 'Heavicrop' collard and Red Green Glaze kale were grown only in the 1993-94 and the 1994-95 studies. All cultural practices (e.g., cultivation, fertilization, and irrigation) used in the field studies were based on commercial standards for the area (Johnson et al., 1987). Daily maximum and minimum air temperatures were recorded throughout the course of all field studies.

The number of leaves per plant was counted biweekly on a subsample of three flagged plants in each plot through January, and then weekly after that until plants were harvested. 
The 20- to 22-leaf stage was designated as a marketable size. If flagged plants reached this size, they were harvested, and the fresh weight and the date of harvest were recorded. Flagged plants bolting before reaching marketable size were harvested and weighed at the date of bolting. Plants were designated as bolted when flower buds exserted from the apical leaf whorl and became visible without moving leaves to expose the growing point. As bolting began, the number of bolted plants per plot was counted every 2 to 3 days. Date of $50 \%$ bolting was recorded. The study at Florence in 1993 was terminated on 15 May, and all studies at Charleston were terminated 30 May because the plants began to deteriorate with the onset of high temperatures.

A "harvest window" was determined and defined as the number of days from the date when plants in a plot attained marketable size to the date $50 \%$ of the plants had bolted. If $50 \%$ of the plants in a plot bolted before reaching marketable size, the harvest window equalled zero. For genotypes that did not reach the $50 \%$ bolt stage, the harvest window equalled the number of days from the date of attaining marketable size to the date the study was terminated. If a genotype did not reach the $50 \%$ bolt stage, the harvest window was usually a maximum value for each respective environment.

In 1992-93 at Florence, the cultivars 'Blue Max' collard and 'Premier' kale reached marketable size earliest and whole plots of these entries were erroneously harvested. Thus, no exact bolting or harvest window data were obtained for these entries in this environment and they were excluded from analysis of the characters. Bolting and harvest window data were obtained for the remaining entries in the Florence test.

Due to the inherent genotypic (Farnham, 1996) and phenotypic (e.g., leaf shape and plant stature) differences between the collard and kale crops, all statistical procedures used to analyze data were conducted separately by crop. Data from all experiments were subjected to analysis of variance using SAS Proc GLM (SAS Institute, Cary, N.C.), and means were separated by a protected LSD at the $P=$ 0.05 significance level.

\section{Results}

The average daily air maxima and minima by month for each winter environment were calculated (Table 1). Of the four winter environments, temperatures were lowest at Florence in Winter 1992-93. The three Charleston winters had similar average monthly temperatures. However, temperatures at Charleston during Feb. and Mar. 1992-93 and Dec. and Jan. 1993-94 were lower than average.

The successful production of marketablesize collard and kale crops in this study was significantly influenced by winter environment and crop genotype. The number of days from transplanting to the $50 \%$ bolt stage and the harvest window length differed among genotypes within each crop in all four winter environments (Figs. 1 and 2). Low-tempera-
Table 1. Mean maximum and minimum daily temperatures $\left({ }^{\circ} \mathrm{C}\right)$ during collard and kale trials at Charleston (Chas) and Florence (Flor), S.C.

\begin{tabular}{|c|c|c|c|c|c|}
\hline \multirow[b]{4}{*}{ Month } & \multirow{4}{*}{$\begin{array}{c}\text { Daily } \\
\text { temperature } \\
\text { parameter }\end{array}$} & \multicolumn{4}{|c|}{ Location } \\
\hline & & Chas & Flor & Chas & Chas \\
\hline & & \multicolumn{4}{|c|}{ Season } \\
\hline & & $\overline{1992-93}$ & $\begin{array}{l}1992-93 \\
\end{array}$ & 1993-94 & 1994-95 \\
\hline \multirow[t]{2}{*}{ November } & Max. & $(18)^{z}$ & (18) & --- & --- \\
\hline & Min. & $(8)$ & (6) & --- & --- \\
\hline \multirow[t]{2}{*}{ December } & Max. & 16 & 13 & (14) & 17 \\
\hline & Min. & 6 & 2 & (2) & 8 \\
\hline \multirow[t]{2}{*}{ January } & Max. & 17 & 14 & 14 & 15 \\
\hline & Min. & 7 & 3 & 3 & 4 \\
\hline \multirow[t]{2}{*}{ February } & Max. & 15 & 14 & 18 & 16 \\
\hline & Min. & 6 & 1 & 6 & 4 \\
\hline \multirow{2}{*}{ March } & Max. & 19 & 17 & 23 & 22 \\
\hline & Min. & 8 & 4 & 10 & 9 \\
\hline \multirow[t]{2}{*}{ April } & Max. & 22 & 22 & 26 & 26 \\
\hline & Min. & 10 & 8 & 13 & 14 \\
\hline \multirow[t]{2}{*}{ May } & Max. & 28 & (29) & 27 & 30 \\
\hline & Min. & 17 & (16) & 16 & 18 \\
\hline
\end{tabular}

${ }^{2}$ Temperatures in parentheses are monthly averages computed only from days of the respective month the trial was conducted.

Table 2. Plant weights at marketable size and the number of days from transplanting to harvest for collard genotypes grown in winter environments at Charleston (Chas) and Florence (Flor), S.C. Entries included in this table attained marketable size before the $50 \%$ bolt stage in $>50 \%$ of the winter environments in which they were tested.

\begin{tabular}{|c|c|c|c|c|c|c|c|c|}
\hline \multirow[b]{5}{*}{ Genotype } & \multicolumn{4}{|c|}{ Plant wt. (g/plant) } & \multicolumn{4}{|c|}{ Days from transplant to harvest } \\
\hline & \multicolumn{8}{|c|}{$\overline{\text { Location }}$} \\
\hline & Chas & Flor & Chas & Chas & Chas & Flor & Chas & Chas \\
\hline & \multicolumn{8}{|c|}{ Season } \\
\hline & 1992-93 & 1992-93 & 1993-94 & 1994-95 & 1992-93 & $1992-93$ & 1993-94 & $1994-95$ \\
\hline Blue Max & 570 & 380 & 624 & 801 & 107 & 147 & 95 & 107 \\
\hline Champion & 637 & 296 & 507 & 760 & 120 & 149 & 96 & 112 \\
\hline Vates & 591 & $(217)^{\mathrm{z}}$ & 429 & 725 & 114 & $(141)$ & 93 & 106 \\
\hline Flash & 601 & (289) & 454 & 878 & 109 & (136) & 92 & 103 \\
\hline G. Summersett & 622 & 597 & 762 & 1168 & 130 & 168 & 109 & 112 \\
\hline Mesic Zero & 640 & 388 & 751 & 733 & 130 & 175 & 117 & 118 \\
\hline $\mathrm{LSD}_{005}$ & NS & 180 & 146 & 248 & 7 & 5 & 4 & 5 \\
\hline
\end{tabular}

${ }^{ } \mathrm{Numbers}$ in parentheses are for plants that had bolted.

Table 3. Plant weights at marketable size and the number of days from transplanting to harvest for kale genotypes grown in winter environments at Charleston (Chas) and Florence (Flor), S.C. Entries included in this table attained marketable size before the $50 \%$ bolt stage in $>50 \%$ of the winter environments in which they were tested.

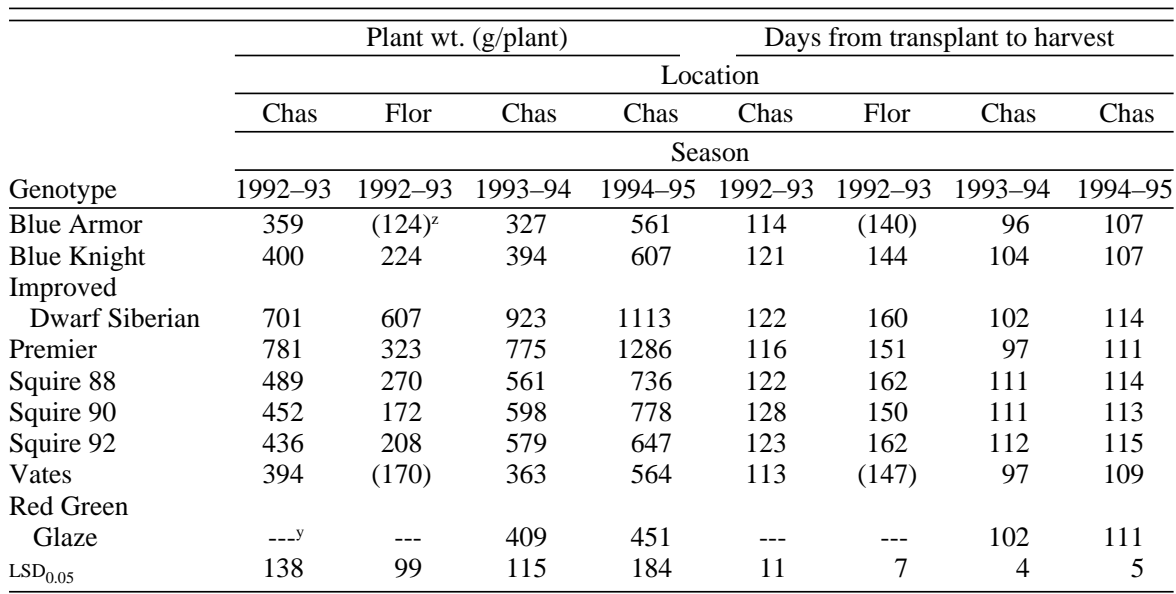

${ }^{2}$ Numbers in parentheses are for plants that had bolted.

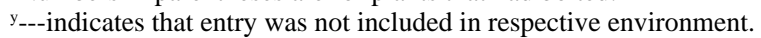


ture damage was not apparent for any entry, and $95 \%$ to $100 \%$ of all plants survived in all environments. Thus, the tendency of a particular genotype to bolt was the limiting factor for crop production in the winter environments of this study.

For collard grown at Charleston in 1992 93 (Fig. 1A) and 1994-95 (Fig. 1D), the range in number of days from transplanting to $50 \%$ bolt stage (or termination of growing season) was identical at 103 to 168 days. The range was 90 to 175 days at Charleston in 1993-94 (Fig. 1C), and 132 to 190 at Florence in 199293 (Fig. 1B). Two collard cultivars, 'Blue Max' and 'Champion', and two open-pollinated landraces, G. Summersett and Mesic Zero, reached marketable size before the $50 \%$ bolt stage in all four winter environments and had the longest harvest windows among all collard entries (Fig. 1A-D). In fact, G. Summersett and Mesic Zero never reached $50 \%$ bolt stage in two and three winter seasons, respectively, and are among the longeststanding genotypes examined. In contrast, the hybrid cultivar 'Top Bunch' and the OP cultivars 'Georgia' and 'Green Glaze' nearly always bolted before reaching marketable size. The relative performance of collard genotypes for days to $50 \%$ bolt and length of the harvest window was similar for all winter environments.

Most kale genotypes (Fig. 2) remained vegetative longer than did collard genotypes (Fig. 1). The number of days to the $50 \%$ bolt stage for kale genotypes ranged from 132 to 185 days at Charleston in 1992-93 (Fig. 2A), 138 to 190 days at Florence in 1992-93 (Fig. 2B), 103 to 175 days at Charleston in 1993-94 (Fig. 2C), and 116 to 180 at Charleston in 1994-95 (Fig. 2D). Essentially, all kale entries attained marketable size before bolting in all winters at Charleston and had a harvest window $>0$. AtFlorence, six of nine entries reached marketable size before the $50 \%$ bolt stage. In general, kale entries had longer harvest windows than did collard entries. The hybrid cultivar 'Blue Knight', the OP cultivar 'Squire 88 ', and two populations derived from 'Squire 88 ' were the longest-standing kale genotypes. With the exception of 'Blue Knight' at Florence, those entries did not bolt in the winter environments of this study.

Average collard weight at harvest and the number of days from transplanting to harvest (when marketable size was attained) varied with winter environment (Table 2). The individual plant weights were lowest (average across harvested entries, $415 \mathrm{~g}$ ) and the number of days to harvest was highest (average of 160 days) for the Florence environment. Under the colder conditions at Florence, individual leaf weight was less than for other environments, and harvested plant weights were likewise lower. Average plant weight (844 g) was highest at Charleston in 1994-95, but collard reached market size in the least time (average of 100 days) at Charleston in 1993-94. The collard cultivars 'Blue Max', 'Champion', 'Vates', and 'Flash', which usually attained marketable size before bolting, generally had similar individual plant weights.
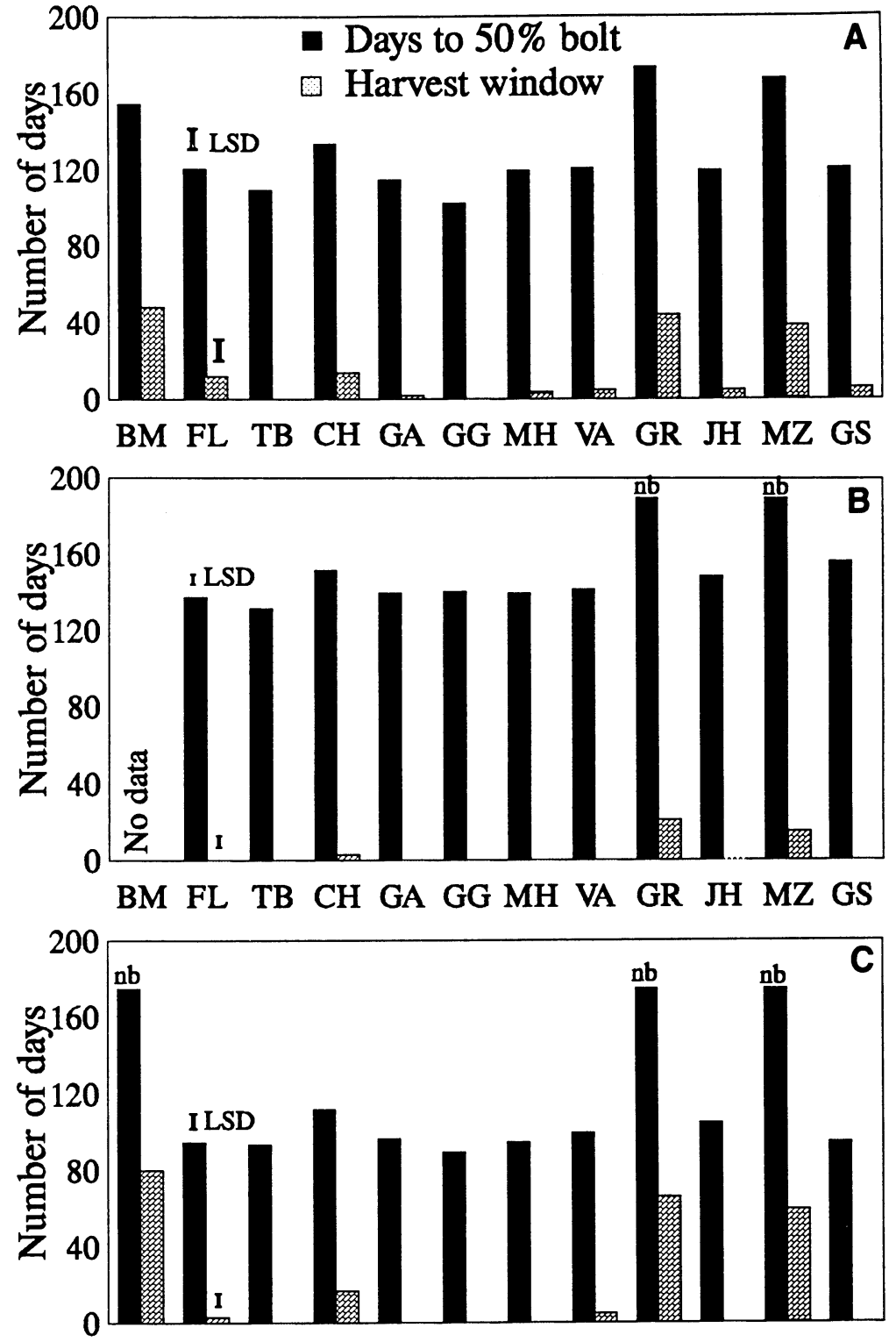

BM FL TB CH GA GG MH VA GR JH MZ HC

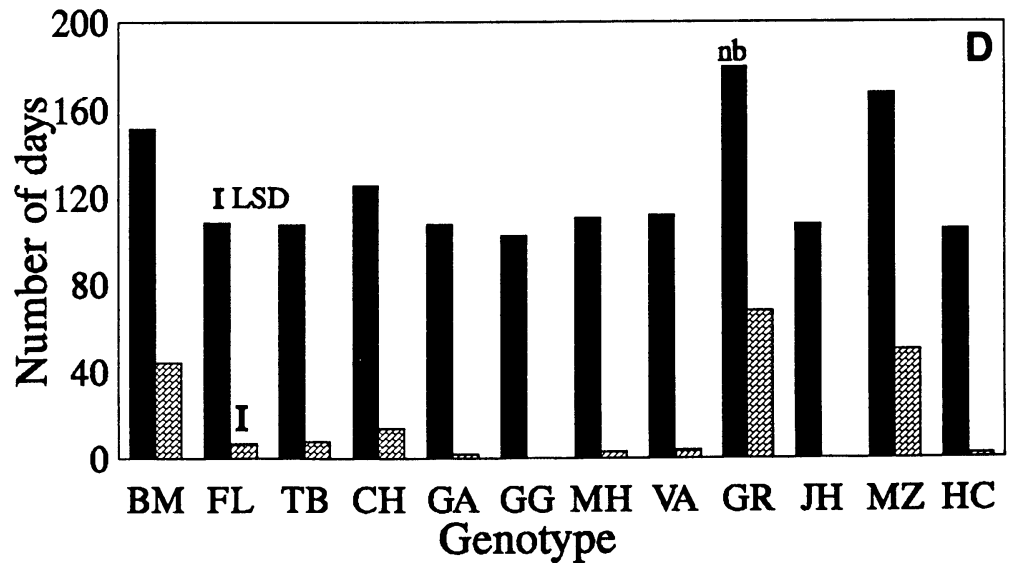

Fig. 1. Collard entry means for the number of days from transplanting to $50 \%$ bolt (or to the end of the growing season) and the number of days for a harvest window with entries grown in winter environments at: (A) Charleston, 1992-93; (B) Florence, 1992-93; (C) Charleston, 1993-94; and (D) Charleston, 1994-95. Vertical bars over columns indicate $\mathrm{LSD}_{0.05}$ for that respective trait in a given environment. " $\mathrm{Nb}$ " indicates that an entry never reached the $50 \%$ bolt stage at termination of the growing season. Collard entries are abbreviated as: BM = 'Blue Max'; FL = 'Flash'; TB = 'Top Bunch'; $\mathrm{CH}=$ 'Champion'; GA = 'Georgia'; GG = 'Green Glaze'; MH = 'Morris Heading'; VA = 'Vates'; GR = G. Summersett; JH = J. Hope; MZ = Mesic Zero; GS = G. Simpson; and HC = 'Heavicrop'. 

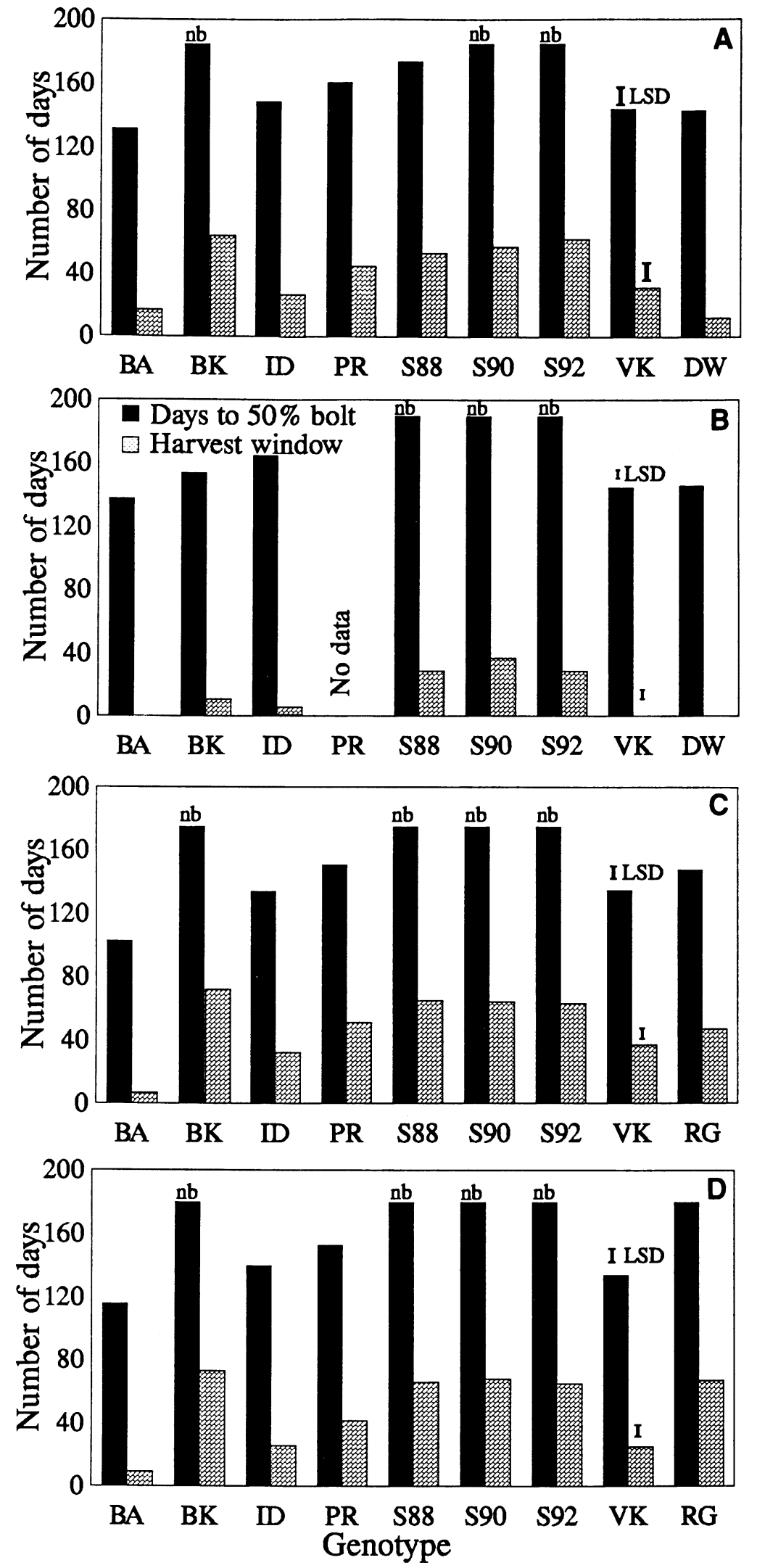

Fig. 2. Kale entry means for the number of days from transplanting to $50 \%$ bolt (or to the end of the growing season) and the number of days for a harvest window with entries grown in winter environments at: (A) Charleston, 1992-93; (B) Florence, 1992-93; (C) Charleston, 1993-94; and (D) Charleston, 1994-95. Vertical bars over columns indicate $\mathrm{LSD}_{0.5}$ for that respective trait in a given environment. "Nb" indicates that an entry never reached the $50 \%$ bolt stage at termination of the growing season. Kale entries are abbreviated as: BA = 'Blue Armor'; BK = 'Blue Knight'; ID = 'Improved Dwarf Siberian'; PR = 'Premier'; S88 = 'Squire 88'; S90 = 'Squire 90'; S92 = 'Squire 92'; VK = 'Vates'; DW = 'Dwarf Blue Scotch'; and RG = Red Green Glaze.
In addition, the number of days to harvest was similar for the four cultivars, but 'Champion' was always slowest of all to attain marketable size. In two environments, the delay for 'Champion' was statistically significant. The two collard landraces, G. Summersett and Mesic Zero, generally weighed more but took longer to attain marketable size than the four collard cultivars cited above.

As observed with collard, average kale weight and days to marketable harvest varied significantly with winter environment (Table 3 ). Also in parallel with collard, lowest average plant weight (300 g) and highest average number of days (155 days) to harvest for kale were observed in the Florence environment. Kale weighed the most (average of $787 \mathrm{~g}$ ) at Charleston in 1994-95, but had the lowest average number of days to harvest (104 days) at Charleston in 1993-94. Among the kale entries, 'Improved Dwarf Siberian' and 'Premier' plants always weighed significantly more and, in general, had a distinctive appearance compared to all other kale entries. These two distinct cultivars are genetically different from the other kales and are more properly labeled "rape kale," species Brassica napus Pabularia Group (Borchers and Taylor, 1983). All other kale entries in the study are best described as "Scotch" kales, the type of kale most widely grown in the United States. Among the Scotch kales, plant weights were similar; however, the 'Squire' populations generally weighed more at harvest than did the others. Significant differences for the number of days from transplanting to harvest were always observed among kale entries in all four winter environments. 'Blue Armor', 'Premier', and 'Vates' usually reached marketable size before other kales, and the 'Squire' populations always reached the harvestable stage last. Other entries exhibited intermediate maturities.

\section{Discussion and Conclusions}

Our findings show that late fall transplanting and use of the winter growing season in climatic zones represented in this study can result in a marketable-size crop of collard and kale before bolting is induced by low temperatures. Currently, collard and kale are harvested during winter months in the southeastern states. However, these crops are not normally directseeded beyond the end of September or transplanted after mid-October. Planting past the above times is not recommended in South Carolina, North Carolina, and most of Georgia, with the exception of the southernmost part of that state (Dufault et al., 1992). Our results indicate that southeastern collard and kale growers might be able to expand their winter production, especially into the month of March, bringing their crops to market when prices are relatively high. Incentives for expanding winter production include the fact that winter is a relatively insect-free season and little need for insecticides can significantly lower production costs. We also generally observed that leaf quality can be very high in these winter cole crops harvested from midMarch through April. Successful winter pro- 
duction of collard and kale from late-autumn transplants requires selecting a long-standing genotype such as 'Blue Max' or 'Champion', in the case of collard, and 'Blue Knight' or 'Squire' for kale. The hybrid cultivars 'Blue Max' collard and 'Blue Knight' kale may each have an advantage over the respective OP cultivars, 'Champion' and 'Squire', in that they usually attain marketable size earlier (Tables 2 and 3).

Collard and kale genotypes used in this research represent essentially all cultivars available in the United States. The additional landraces and breeding lines were included in this research to broaden the germplasm base evaluated and to examine the potential of identifying long-standing entries outside the pool of available cultivars. Timing of bolting differs significantly among collard and kale genotypes, with some genotypes bolting consistently early and others bolting much later or not at all. These findings are consistent with those of Knott and Hanna (1947) for cabbage (B. oleracea L. Capitata Group). Observations from our study also confirm that selection for delayed bolting in 'Vates' collard, as one example, to develop the slow-bolting 'Champion', was effective (Borchers and Taylor, 1979). This realized gain from selection for delayed bolting, combined with our observations of similar, relative performance of genotypes for the number of days to $50 \%$ bolt stage and attainment of marketable yield before bolting across winter environments, provides evidence that there is significant genetic control of the delayed-bolting, i.e., long-standing, phenotype. It is noteworthy that two landraces, G. Summersett and Mesic Zero, collected from a South Carolina and a North Carolina gardener, respectively, were among the longeststanding entries evaluated. These two entries are apparently well adapted to winter production in the test climates, growing large and standing for a long period of time before bolting. Although G. Summersett and Mesic Zero would not be acceptable as commercial cultivars due to particular undesirable characteristics (e.g., excessive variation among plants within each population), it is possible that these landraces contain genes that could be incorporated into existing cutivars to enhance the ability of cultivated genotypes to grow and produce in a winter environment.

\section{Literature Cited}

Borchers, E.A. 1990. 'Squire' a new short-stemmed, longstanding kale. Veg. Growers News, Virginia Coop. Ext. Serv. 44:1.
Borchers, E.A. and R.T. Taylor. 1979. Champion collard, a new longstanding collard. Veg. Growers News, Virginia Truck and Orn. Res. Sta. 34:1.

Borchers, E.A. and R.T. Taylor. 1983. Premier, a new longstanding kale. Veg. Growers News, Virginia Truck and Orn. Res. Sta. 38:1.

Dufault, R.J., D.R. Decoteau, J.T. Garrett, R.T. Nagata, K.D. Batal, W.J. McLaurin, D.M. Granberry, K.B. Perry, and D. Sanders. 1992. Scheduling collard planting dates regionally to lengthen the production period. HortTechnology 2:64-66.

Farnham, M.W. 1996. Genetic variation among and within United States collard (Brassica oleracea L.) cultivars and landraces as determined by random amplified polymorphic DNA markers. J. Amer. Soc. Hort. Sci. 121:374-379.

Johnson J.R., R.P. Griffin, and C.E. Drye. 1987. Commercial collard production. Hort. Lflt. 5. Clemson Univ. Coop. Ext. Serv., Clemson, S.C.

Knott, J.E. and G.C. Hanna. 1947. The effect of widely divergent dates of planting on the heading behavior of seven cabbage varieties. Proc. Amer. Soc. Hort. Sci. 49:299-303.

Parham, P.H. and E.L. Moore. 1959. The effect of low temperature exposures on the vegetative and reproductive growth of collards. Proc. Amer. Soc. Hort. Sci. 73:367-373.

SAS Institute. 1985. User's guide: Statistics. 5th ed. SAS Institute, Cary, N.C.

Warne, L.G.G. 1961. Juvenile stage in cultivated forms of Brassica oleracea. Nature 192:889. 